\title{
Ficus deltoidea aqueous leaves extract abrogates enhanced-oxidative damage in ovariectomized rat models
}

\author{
Farah Wahida Ibrahim ${ }^{1,2}$ (D), Aida Farahin Abdullah ${ }^{1}$, Chan Yee Ling ${ }^{1}$, Nurul Farhana Jufri ${ }^{1,2}$, Nihayah Mohammad ${ }^{1}$, \\ Nor Fadilah Rajab ${ }^{1,3^{*}}$ \\ ${ }^{1}$ Biomedical Science Program, Faculty of Health Sciences, Universiti Kebangsaan Malaysia, Kuala Lumpur, Malaysia. \\ ${ }^{2}$ Center for Toxicology and Health Risk Studies (CORE), Faculty of Health Sciences, Universiti Kebangsaan Malaysia, Kuala Lumpur, Malaysia. \\ ${ }^{3}$ Center for Healthy Aging \& Wellness (H-CARE), Faculty of Health Sciences, Universiti Kebangsaan Malaysia, Kuala Lumpur, Malaysia.
}

\begin{tabular}{l}
\hline ARTICLE INFO \\
\hline Received on: $14 / 10 / 2020$ \\
Accepted on: 02/01/2021 \\
Available online: 05/08/2021 \\
\hline Key words: \\
Antioxidant, estrogen, Ficus \\
deltoidea, ovariectomized- \\
rats, oxidative stress, \\
menopause.
\end{tabular}

\begin{abstract}
The aim of the study is to investigate the potential of Ficus deltoidea aqueous extract in protecting the vital organs of female rats against ovariectomy-induced oxidative stress. The rats were grouped into control intact (normal saline), ovariectomized control (OVX), and ovariectomized rats fed orally with $500 \mathrm{mg} / \mathrm{kg}$ F. deltoidea extract (OVX+T). Upon treatment completion, the collected organs were homogenized and measured for malondialdehyde (MDA), superoxide dismutase (SOD), glutathione (GSH), catalase (CAT), and glutathione peroxidase (GPx). Serum total cholesterol (TC) was also measured. MDA levels were found to increase in the heart and brain of OVX rats. Ovariectomy caused a decrease in the GSH levels and reduced CAT, SOD, and GPx enzyme activities in the organs of the OVX rats. Ovariectomy also caused an increase in serum TC level. The $F$. deltoidea leaves extract supplementation not only reduced the MDA levels and increased GSH levels and CAT activities in the selected organs of the OVX+T rats but also decreased the TC level in serum. Glutathione (GPx) activity was found to be increased only in the heart and kidney of the $\mathrm{OVX}+\mathrm{T}$ rats. In conclusion, F. deltoidea aqueous extract has the potential to be developed as an antioxidant supplement to protect the vital organs against oxidative damages during the postmenopausal condition.
\end{abstract}

\section{INTRODUCTION}

Enhanced oxidative stress and decreased antioxidant defense in postmenopausal women as compared to premenopausal women play an important role in the pathogenesis of various diseases related to menopause (Aroka et al., 2009). For example, the incidence of cardiovascular morbidity and mortality in women after menopause was more prominent compared to premenopausal women (Skafar et al., 1997). These might be due to the loss of protective effects provided by estrogen as it is widely documented that this hormone has protective actions in stimulating the oxidative defense system and inhibits oxidative stress (Kerstin

\footnotetext{
${ }^{*}$ Corresponding Author

Nor Fadilah Rajab, Biomedical Science Program, Center for Healthy Aging \& Wellness (H-CARE), Faculty of Health Sciences, Universiti Kebangsaan Malaysia, Kuala Lumpur, Malaysia.

E-mail:nfadilah@ukm.edu.my
}

et al., 2003). In addition, estrogen exerts its protective effects on several organs such as the brain, liver, kidney, and heart. Previous studies have shown that estrogen was neuroprotective by preventing intracellular peroxide accumulation in neurons (Behl et al., 1997), hepatoprotective against inflammation and oxidative stress (Shimizu et al., 2007), nephroprotective by attenuating glomerulosclerosis and tubulointerstitial fibrosis (Gluhovschi et al., 2012), and protective against atherosclerosis by modulating low-density lipoprotein (LDL) oxidation, binding of free radicals, and lowering plasma cholesterol (Barp et al., 2009). However, these protective abilities are declined as the women undergo the menopausal process.

Oxidative stress is the term used to explain the oxidative damages in cells, tissues, or organs due to reactive oxygen species (ROS). Oxidative stress occurs when there is an imbalance between the oxidant and the antioxidant system. Superoxide anion $\left(\mathrm{O}_{2} \cdot-\right)$, hydrogen peroxide $\left(\mathrm{H}_{2} \mathrm{O}_{2}\right)$, and hydroxyl radical are ROS species that target proteins, nucleic acids, or lipid structures and eventually cause tissue damage 
(Fang et al., 2002). The addition of oxygen radical to the polyunsaturated fatty acid (PUFA) of lipids causes oxidative damage that resulted in the production of malondialdehyde (MDA). MDA is the end product of lipid peroxidation (LPO) and thus is used as a marker of oxidative stress. To protect the body against the scavenging activity of the ROS, the body has a built-in defense antioxidant mechanism that consists of superoxide dismutase (SOD), catalase (CAT), and glutathione peroxidase (GPx). SOD neutralizes the $\mathrm{O}_{2} \cdot$ - radicals to $\mathrm{H}_{2} \mathrm{O}_{2}$ while $\mathrm{GPx}$ reduces $\mathrm{H}_{2} \mathrm{O}_{2}$ with reduced glutathione $(\mathrm{GSH})$ to water and oxygen. Meanwhile, CAT will disassociate $\mathrm{H}_{2} \mathrm{O}_{2}$ to water and oxygen (Salvi et al., 2007).

Postmenopausal women are more vulnerable to estrogendeficiency-induced oxidative stress than their premenopausal counterparts. To date, researchers have been searching for an alternative treatment to reduce the impact of oxidative stress in menopausal women. Foods rich in antioxidants have been shown to be of great benefit in women experiencing menopausal symptoms because they help to eliminate oxidative stress within the body (Doshi and Agarwal, 2013). The natural product has been favorably used for health and medicinal purposes long before drugs ever being invented. A wide variety of natural products are being used to treat ailments, known as traditional medicine. Current estimation states that $80 \%$ of the overall population still depends on traditional medicines to fulfill their health care needs as an alternative to regular medication (WHO, 2008). Previous studies on the effectiveness of herbal preparations to manage the symptoms of menopause have been carried out on Labisia pumila, Cimicifuga racemosa, and Trifolium pratense (Beral et al., 2002; Stacie et al., 2009). These herbs contain phytoestrogens, which have a similar chemical structure to human estrogen, thus able to bind to estrogen receptors in human and elicit downstream signaling (Glazier and Marjorie, 2001).

Interestingly, in Malaysia, a traditional plant known as Ficus deltoidea or locally known as Mas Cotek, is popular among traditional medical practitioners. Ficus deltoidea that grows in the Peninsular of Malaysia has different varieties (Fatihah et al., 2012). All parts of the plant including the roots, bark, leaves, and fruits are reported to have medicinal benefits with therapeutic potentials (Abdulla et al., 2010; Adam et al., 2007; Azizan et al., 2017; Bunawan et al., 2014; Kamran et al., 2020; Misbah et al., 2013). The aqueous preparation of $F$. deltoidea leaves is traditionally used to assist in parturition and after birth, as it has the ability to stimulate uterine contraction (Ibrahim et al., 2018; Sulaiman et al., 2008; Zainudin et al., 2014). The leaves also can be used in tea beverages with a good source of minerals (Nihayah et al., 2012). Besides, it has been reported to possess antihypertensive effects (Aminudin et al., 2007) as well as antioxidant and antiinflammation properties (Abdullah et al., 2009). Ficus deltoidea is also able to reduce both blood glucose level (Adam et al., 2007) and cancer risk (Aris et al., 2009). Findings by Hakiman and Maziah (2009) found that $F$. deltoidea contains phytochemical properties that are related to flavonoid and phenolic compounds. These two antioxidants are capable of delaying or inhibiting the oxidation of lipids or other biomolecules by inhibiting the initiation or propagation of oxidizing chain reactions (Sirisha et al., 2010). However, the benefit of this traditional herb in alleviating oxidative stress in the brain, liver, heart, and kidney due to estrogen deficiency has not been proven to the best of our knowledge. This study aims to investigate and scientifically prove that the reported antioxidant property of $F$. deltoidea aqueous extract has the potential to protect against ovariectomy-induced oxidative stress in the brain, liver, heart, and kidney of rats.

\section{METHODOLOGY}

\section{Animals and study design}

Twenty-four virgin female Sprague-Dawley rats, aged three months old and weighing between 200 and $250 \mathrm{~g}$, were divided into three groups, with $n=8$ rats/group. The animals were housed paired and kept at $24^{\circ} \mathrm{C}$ with a $12: 12$-hours light-dark cycle. Only virgin female rats were used in this study to minimize hormonal influence variations between animals. The rats were fed with food and water made available ad libitum. The groups were (1) sham-operated (control); (2) ovariectomized rats with orally fed vehicle (distilled water) ovariectomized control (OVX), and (3) ovariectomized rats and orally fed with $500 \mathrm{mg} / \mathrm{kg} \mathrm{F}$. deltoidea $(\mathrm{OVX}+\mathrm{T})$ via oral route for 28 days. The rats were anesthetized and the ovaries were bilaterally removed via dorsal approach. Ovariectomized female rats were used to ensure the relative homogeneity of the animals' endogenous hormonal background and to eliminate potential interference from ovarian factors (SchirmanHildesheim et al., 2006). Here, in this study, ovariectomized rats were used as a menopausal animal model as it creates intrinsic changes in the body biochemistry and physiological function in these animals similar to those of menopausal women (Bosse and Di Paolo, 1995). The dorsal part of the lumbar region was cleared off and disinfected with $70 \%$ ethanol. Only one incision of $1.5 \mathrm{~cm}$ was made on the cleared skin and another $1 \mathrm{~cm}$ incision on the muscle wall on each side of the backbone. The ovaries were located and removed after the uterine horns were tied with sterile sutures. The incision on the skin was closed with skin staples. After surgery, the animals were housed individually for one day. Then, the animals were pair-housed and allowed to recover for 6-7 days before further manipulations. All postoperative animals were monitored closely for any indicator of pain or distress according to the Animal Ethical Committee (AEC) guidelines. Animals that were affected were excluded from the experiment and euthanized appropriately. Rats were anesthetized using a cocktail of Ketamine-Zoletil-Xylazine (KTX) with a dose of $0.4 \mathrm{ml} / \mathrm{kg}$ intraperitoneally. For sham-operated rats, the ovaries were left intact. All rats were given a two-week recovery period before the $F$. deltoidea treatment protocol started. This study was granted approval from the Universiti Kebangsaan Malaysia Animal Ethics Committee (UKMAEC): FSK/BIOMED/2012/FARAH/12Dec/483-DEC- 2012-JUNE-2013.

\section{Samples collection}

At the end of the 28-day treatment regime, the animals were anesthetized and blood samples were taken via cardiac puncture and collected in the plain tubes. The blood samples were left for 1-3 hours at room temperature and were centrifuged at $3,000 \mathrm{rpm}$ at $4{ }^{\circ} \mathrm{C}$ for 10 minutes. Serum was collected and stored at $-20^{\circ} \mathrm{C}$ until further investigation. Brain, heart, liver, and kidney were harvested and washed with ice-cold $1.15 \%(w / v)$ potassium chloride $(\mathrm{KCl})$. Each of the tissue samples was homogenized by adding $1.15 \% \mathrm{KCl}$ with a ratio of $3 \mathrm{ml} / \mathrm{g}(v / w)$. The tissue 
homogenates were centrifuged at $8,000 \mathrm{rpm}$ at $4^{\circ} \mathrm{C}$ for 20 minutes and stored at $-20^{\circ} \mathrm{C}$ until further use.

\section{Plant extract preparation}

The leaves were collected from Juaseh Tengah, Negeri Sembilan, Malaysia, and were brought to Herbarium UKMB for identification (voucher specimen UKMB29781). The leaves were extracted as described by Zainudin et al. (2014). Briefly, $300 \mathrm{~g}$ of the dried leaves were cut into smaller pieces and extracted with distilled water using Soxhlet apparatus. The resultant product was filtered and later freeze-dried before being diluted with distilled water to the desired concentration

\section{MDA level and total antioxidant status}

The LPO level via MDA quantification was adapted from the Ledwozyw et al. (1986) method and measured at $532-535 \mathrm{~nm}$, whereas the total antioxidant status was measured via SOD, CAT, and GPx activities. SOD was detected via Beyer and Fridovich (1987) method at $560 \mathrm{~nm}$, while CAT activity was measured by the Aebi (1984) method at $240 \mathrm{~nm}$. The activity of GPx activity was quantitated based on Paglia and Valentine (1967) method at $340 \mathrm{~nm}$. These tests were carried out on tissue homogenates by measuring the designated optical density using a spectrophotometer (Secomam, France). The MDA level was measured in $\mathrm{nmol} / \mathrm{mg}$, the SOD level in UE/minute $/ \mu \mathrm{g}$, the CAT level in UE/mg, and GPx in UE/ $\mu$ g.

\section{GSH level}

GSH level was measured as described by Ellman (1959). The GSH in the sample reacted with the Ellman reagent to produce a red-colored product that can be measured at $415 \mathrm{~nm}$ by a spectrophotometer. The GSH level was measured in $\mathrm{nmol} / \mu \mathrm{g}$.

\section{Total serum cholesterol level}

The serum cholesterol level was determined using cholesterol high-density lipoprotein (HDL) Direct (Biosystems, Spain). Ten $\mu \mathrm{l}$ serum was added to a $1.0 \mathrm{ml}$ cholesterol reagent. Next, the mixture was incubated at $37^{\circ} \mathrm{C}$ for 5 minutes and the optical density was measured at $500 \mathrm{~nm}$ using Bioanalyzer (Biosystem, Spain). The cholesterol level was measured in mmol/L.

\section{Statistical analysis}

Data analysis was performed using IBM Statistical Package for the Social Sciences Statistics for Windows, Version 19.0 (Armonk, New York). Statistical significance was determined via oneway analysis of variance followed by Tukey's honestly significant difference (HSD) for normally distributed data with $p<0.05$. The results were presented as means \pm standard error of the mean (SEM).

\section{RESULTS AND DISCUSSION}

Estrogen deficiency in postmenopausal women often leads to oxidative stress (Doshi and Agarwal, 2013). A low level of estrogen has prooxidant effects as it can lead to oxidation of bases, the formation of DNA adduct, and breakage of genetic material (Doshi and Agarwal, 2013). These, in turn, resulted in increased ROS-induced tissue damages that are the basis for a number of diseases and biochemical disorders (Murugananthan and Sathya, 2012). The antioxidant is widely used as a therapeutic approach to overcome oxidative stress, as it can remove free radicals and protects the body from detrimental oxidative damages. As plants are one of the best sources of antioxidants (Sen et al., 2010), thus, the current study was conducted to investigate the antioxidant properties of $F$. deltoidea aqueous leaves extract on ovariectomized rats as an estrogen-deficiency model to recapitulate postmenopausal women.

Organs in the body are constantly exposed to the threat of oxidative stress. In women, ovarian estrogen deficiency during menopause accelerates aging by decreasing the body's defense against oxidative stress. Oxidative stress activates multiple intracellular signalings that often lead to organ dysfunctions and damages (Ogura and Shimosawa, 2014). The brain is more susceptible to oxidative damages since it has a high content of PUFA (Peet, 2002). Since estrogen has dual functions as an antiinflammatory as well as antioxidant, it has been known to exert a protective role in organs. Estrogen deficiency affects the brain in such a way that it has been reported to be closely related to the pathogenesis of various neurodegenerative diseases such as Parkinson's and Alzheimer's disease (Norbury et al., 2003). Besides the brain, liver is one of the sources of oxidative stress as liver damage increases ROS production (Jaeschke et al., 2002). The liver of ovariectomized mice showed high LPO and decreased antioxidant enzymes (Oliveira et al., 2018). The heart, on the other hand, showed deterioration in function following the loss of ovarian estrogen which is reversible through estrogen supplementation (Firth et al., 2020). Furthermore, the presence of estrogen was reported to diminish angiotensin II-induced free radical production in vascular smooth muscle cells and upregulated manganese SOD and extracellular SOD expressions and activities in the cardiovascular system (Kerstin et al., 2003). Another organ susceptible to oxidative stress is the kidney. Estrogen exposure inhibits the mitogenic effect of free radicals on human glomerular mesangial cells (Dubey and Jackson, 2001), thus implicating estrogen's impact inon the kidney in its absence.

\section{LPO status}

In this study, bilateral removal of the ovaries in the female rats induced oxidative stress in the vital organs. This was evidenced by the significant increase in the MDA level in the heart $(1.048 \pm 0.003 \mathrm{nmol} / \mathrm{mg})$ and liver $(3.08 \pm 0.365 \mathrm{nmol} / \mathrm{mg})$ of OVX rats compared to the control groups $(1.022 \pm 0.005 \mathrm{nmol} / \mathrm{mg}$ and $1.561 \pm 0.211 \mathrm{nmol} / \mathrm{mg}$, respectively) (Fig. 1). MDA is an indicator of LPO of PUFA of the cell membrane. Estrogen deficiency can cause the excessive formation of ROS. This often leads to LPO as less estrogen is able to bind to the estrogen receptors in order to upregulate the expression of the antioxidant enzyme via the intracellular signaling pathways (Borras et al., 2010; Sridhar et al., 2005). The levels of MDA in the OVX $+\mathrm{T}$ groups were significantly lower in the heart $(1.026 \pm 0,006 \mathrm{nmol} / \mathrm{mg})$, liver $(2.053 \pm 0.235$ $\mathrm{nmol} / \mathrm{mg})$, kidney $(1.042 \pm 0.004 \mathrm{nmol} / \mathrm{mg})$, and brain $(4.513 \pm$ $\mathrm{nmol} / \mathrm{mg})$ compared to the OVX groups $(1.048 \pm 0.003 \mathrm{nmol} /$ $\mathrm{mg}, 3.08 \pm 0.365 \mathrm{nmol} / \mathrm{mg}, 1.056 \pm 0.004 \mathrm{nmol} / \mathrm{mg}$, and 4.513 $\pm 0.906 \mathrm{nmol} / \mathrm{mg}$, respectively) ( $p<0.05)$. These observations suggested that $F$. deltoidea leaves aqueous extract has the potential as an exogenous antioxidant source to complement endogenous antioxidant capacity. Furthermore, the aqueous extract of Ficus deltoidea leaves also has been known to contain flavonoids (Omar 


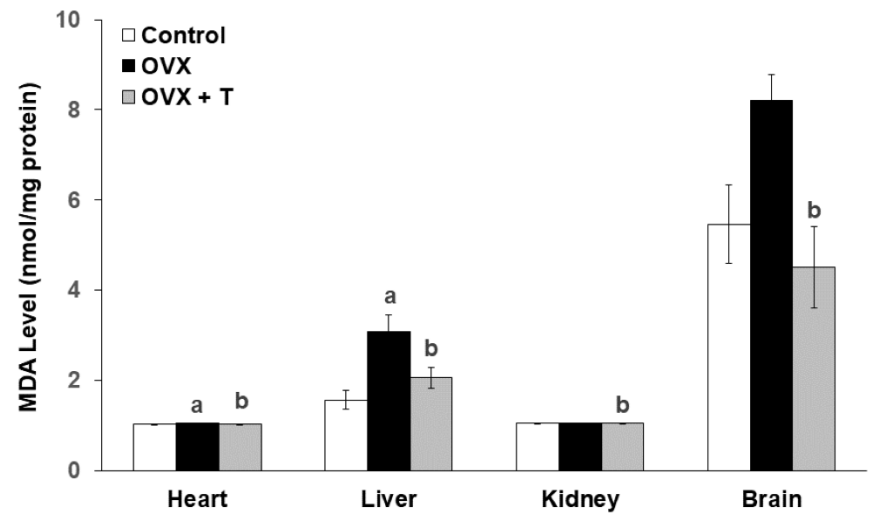

Figure 1. The level of MDA in the heart, liver, kidney, and brain of experimental rats. Data are presented as means \pm SEM. (a) Significant difference compared with control group $(p<0.05)$ and (b) significant difference compared with OVX group $(p<0.05)$.

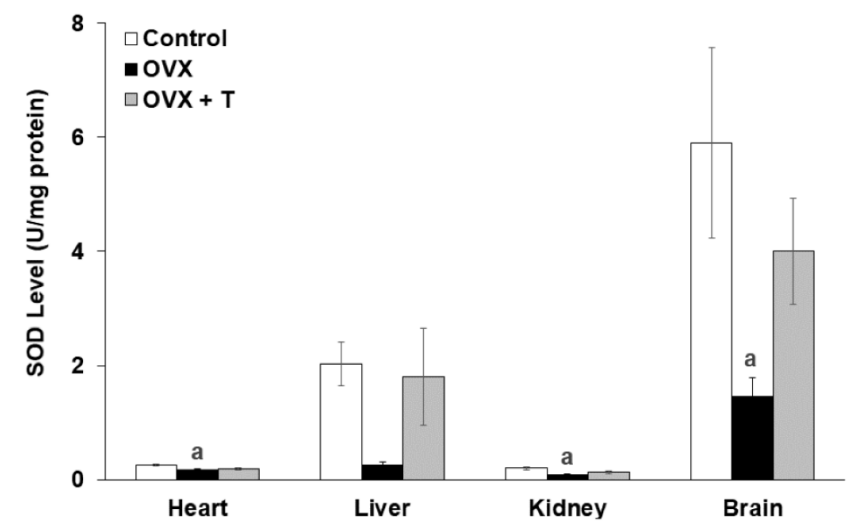

Figure 2. The level of SOD in the heart, liver, kidney, and brain of experimental rats. Data are presented as means \pm SEM. (a) Significant difference compared with control group $(p<0.05)$ and (b) significant difference compared with OVX group $(p<0.05)$.

et al., 2011; Zainudin et al., 2014), phytochemicals that also have been shown to possess estrogenic activities, phytochemicals that also have been shown to possess estrogenic activities.

\section{Antioxidant status}

All antioxidant enzymes were found to be reduced in ovariectomized rats as demonstrated in the previous study by $\mathrm{Ha}$ (2004). SOD is an enzyme used to convert superoxide ion to $\mathrm{H}_{2} \mathrm{O}_{2}$, which is then converted by GPx and CAT to oxygen and water (Nazrun et al., 2008). In the current study, ovariectomy had caused the level of SOD enzyme activity (Fig. 2) to be significantly lower in the heart $(0.167 \pm 0.025 \mathrm{U} / \mathrm{mg})$, kidney $(0.083 \pm 0.016 \mathrm{U} / \mathrm{mg})$, and brain $(1.457 \pm 0.329 \mathrm{U} / \mathrm{mg})$ of OVX groups compared to the control groups (brain: $5.901 \pm 1.664 \mathrm{U} / \mathrm{mg}$, heart: $0.255 \pm 0.020$ $\mathrm{U} / \mathrm{mg}$, and kidney: $0.197 \pm 0.028 \mathrm{U} / \mathrm{mg})(p<0.05)$. Likewise, the CAT enzyme activity (Fig. 3 ) in the OVX groups was also significantly lower in the heart $(0.666 \pm 0.071 \mathrm{U} / \mathrm{mg})$, liver $(0.564$ $\pm 0.054 \mathrm{U} / \mathrm{mg})$, kidney $(0.85 \pm 0.169 \mathrm{U} / \mathrm{mg})$, and brain $(0.948 \pm$ $0.089 \mathrm{U} / \mathrm{mg})$ when compared to the control groups $(1.484 \pm 0.26$ $\mathrm{U} / \mathrm{mg}, 1.812 \pm 0.237 \mathrm{U} / \mathrm{mg}, 1.976 \pm 0.169 \mathrm{U} / \mathrm{mg}$, and $3.548 \pm$ $0.232 \mathrm{U} / \mathrm{mg}$, respectively) $(p<0.05)$.

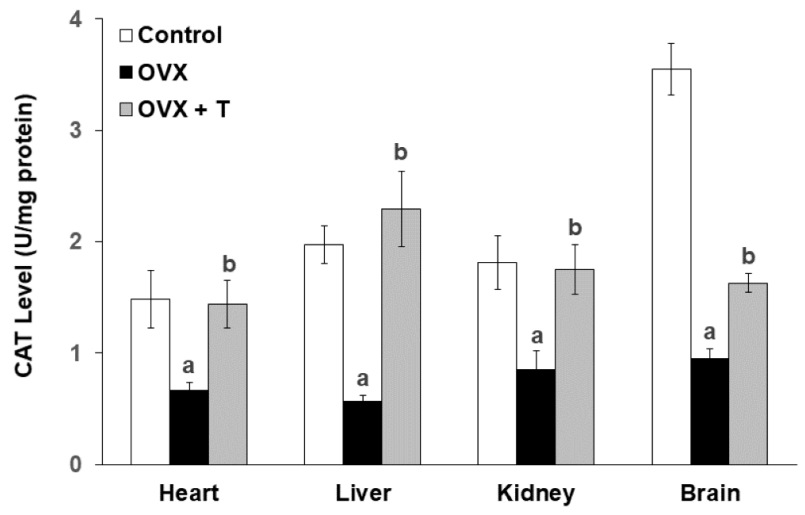

Figure 3. The level of CAT in the heart, liver, kidney, and brain of experimental rats. Data are presented as means \pm SEM. (a) Significant difference compared with control group $(p<0.05)$ and (b) significant difference compared with OVX group $(p<0.05)$.

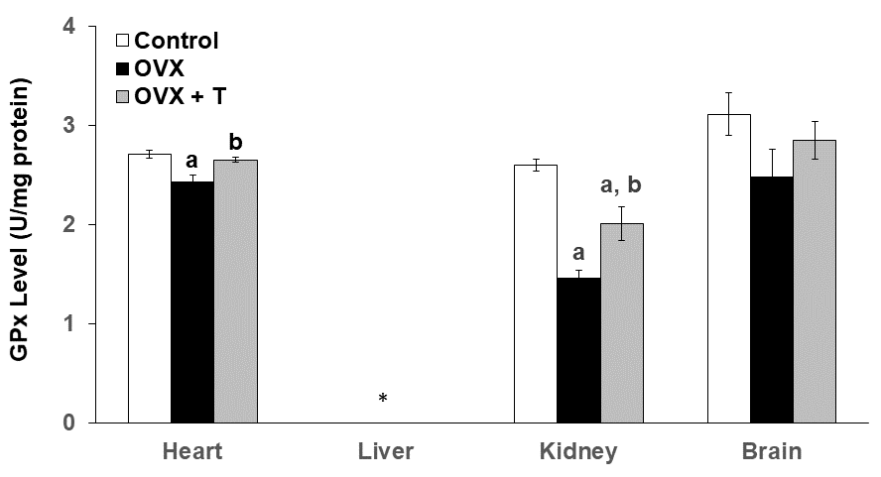

Figure 4. The level of GPx in the heart, liver, kidney, and brain of experimental rats. *The data for liver are unavailable for data analysis. Data are presented as means \pm SEM. (a) Significant difference compared with control group $(p<0.05)$ and (b) significant difference compared with OVX group $(p<0.05)$.

Supplementation with $F$. deltoidea for 28 days in the $\mathrm{OVX}+\mathrm{T}$ group did not show any significant elevation in the SOD activity in the vital organs although the increasing trends were observed (Fig. 2). There were, however, a significant increase in CAT level in the heart $(1.435 \pm 0.214 \mathrm{U} / \mathrm{mg})$, kidney $(1.75 \pm 0.220$ $\mathrm{U} / \mathrm{mg})$, liver $(2.294 \pm 0.338 \mathrm{U} / \mathrm{mg})$, and brain $(1.628 \pm 0.084 \mathrm{U} /$ $\mathrm{mg}$ ) compared to OVX groups $(p<0.05)$ (Fig. 3$)$. In all, CAT and SOD levels were observed to decrease following ovariectomy but supplementation with $F$. deltoidea prevented the reduction by increasing the endogenous enzyme activities instead.

The glutathione peroxidase (GPx) enzyme activity in the OVX groups was significantly lower in both the heart $(2.428 \pm$ $0.072 \mathrm{U} / \mathrm{mg})$ and kidney $(1.456 \pm 0.081 \mathrm{U} / \mathrm{mg})$ organs compared to the control groups (heart: $2.711 \pm 0.038 \mathrm{U} / \mathrm{mg}$ and kidney: 2.600 $\pm 0.060 \mathrm{U} / \mathrm{mg})(\mathrm{p}<0.05)$ (Fig. 4). On the other hand, ovariectomy had caused the rats from the OVX groups to exhibit lower GSH levels in the heart $(8.780 \pm 0.815 \mathrm{nmol} / \mathrm{mg}$ protein $)$, kidney of OVX $(9.710 \pm 0.792 \mathrm{nmol} / \mathrm{mg}$ protein $)$, and brain $(8.480 \pm 0.671$ $\mathrm{nmol} / \mathrm{mg}$ protein) compared to the rats from the control groups (heart: $12.872 \pm 0.651 \mathrm{nmol} / \mathrm{mg}$, kidney: $13.435 \pm 0.972 \mathrm{nmol} / \mathrm{mg}$, and brain: $11.942 \mathrm{nmol} / \mathrm{mg} \pm 0.350)(p<0.05)$ (Fig 5). GSH is the cofactor of GPx used for the completion of the antioxidant system 
(Li et al., 2000). According to Lu (2009), this intracellular peptide has diverse functions that include detoxifications, modulation of cell proliferation, and antioxidant defense. A large reserve of GSH is present in hepatocytes and erythrocytes for the detoxification of free radicals (Ha, 2004). Thus, the dysregulation of GSH synthesis may contribute to oxidative stress and later development for the pathological condition.

Interestingly, supplementation with $F$. deltoidea significantly increased the GPx level only in the heart $(2.651 \pm$ $0.027 \mathrm{U} / \mathrm{mg})$ and kidney $(2.012 \pm \mathrm{U} / \mathrm{mg})$ of $\mathrm{OVX}+\mathrm{T}$ groups when compared to the negative OVX control group, but not in the other two organs (heart and liver). The data for the level of GPx in the liver, however, cannot be determined due to technical issues (Fig 4). Similarly, GSH levels in the heart $(11.635 \pm 0.704 \mathrm{nmol} / \mathrm{mg}$ protein), liver $(17.646 \pm 0.0 .459 \mathrm{nmol} / \mathrm{mg})$, kidney $(13 . \pm 0.182$ $\mathrm{nmol} / \mathrm{mg}$ protein), and brain $(10.430 \pm 0.219 \mathrm{nmol} / \mathrm{mg}$ protein) all showed significant elevation upon $F$. deltoidea aqueous extract supplementation $(p<0.05)$. Interestingly, supplementation with $F$. deltoidea increases GSH level in all organs of ovariectomized rats suggesting that $F$. deltoidea has the potential in regulating GSH level (Fig. 5).

Previously, $F$. deltoidea is documented to contain flavonoids, tannins, proanthocyanins, and phenols, which are known to be responsible for strong antioxidant properties (Rosnani et al., 2012). In addition, Omar et al. (2011) has identified flavan-3ol monomer and proanthocyanidins as the main compounds for this property. Meanwhile, another study demonstrated that F. deltoidea was a potent antioxidant as shown via its scavenging free radical activities of more than 50\% in 2,2-diphenyl-1-picrylhydrazyl assay (Ruzaina et al., 2009). In contrast, the findings from this study suggested that $F$. deltoidea exerts its antioxidant potential via increasing the level of the antioxidant enzymes in the organs of ovariectomized rats, thus highlighting the potential of $F$. deltoidea in combating ROS.

\section{Serum total cholesterol (TC) level}

The TC level in OVX $(2.636 \pm 0.036 \mathrm{mmol} / \mathrm{l})$ was significantly $(p<0.05)$ higher than the control group $(2.184 \pm$ $0.120 \mathrm{mmol} / \mathrm{l})$. The concentration of cholesterol was significantly

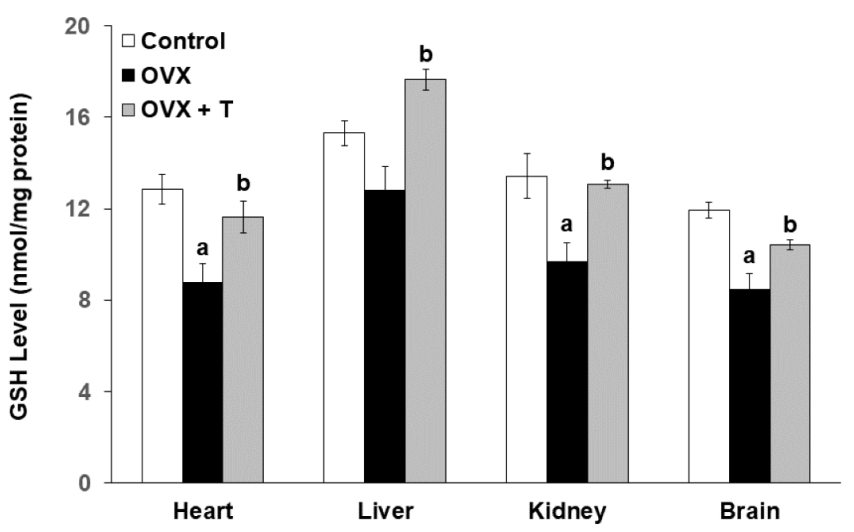

Figure 5. The level of GSH in the heart, liver, kidney, and brain of experimental rats. Data are presented as means \pm SEM. (a) Significant difference compared with control group $(p<0.05)$ and (b) significant difference compared with OVX group $(p<0.05)$. $(p<0.05)$ decreased in ovariectomized rats after treatment with $F$. deltoidea $(2.316 \pm 0.058 \mathrm{mmol} / \mathrm{L})$ in comparison to OVX (Fig. 6). Both estrogen and progesterone influence cardiovascular function (Thomas and Pang, 2013; White et al., 2010). Women in the menopause stage lost protective functions against oxidative stress due to the diminishing ovarian hormones and oxidative stress is one of the risk factors for cardiovascular diseases (Brunelli et al., 2017). Estrogen level can affect cholesterol as (LDL-c) level rises and HDL-c level declines after menopause (Guetta and Cannon, 1996). Estrogen induces hepatic LDL-c receptors for LDL-c catabolism; thus, low estrogen levels may increase LDL-c (Bittner, 2001).

Menopausal women with metabolic syndrome who were given ovarian hormonal therapy have shown reduced oxidative stress and improvements in serum triglyceride and high-density lipoprotein cholesterol (HDL-c) levels (Sánchez-Rodríguez et al., 2016).

Supplementation with $F$. deltoidea was found to decrease the serum TC level and this clearly indicates its potential in regulating cholesterol level. This finding is further supported by Taufik et al. (2005) that reported that $F$. deltoidea extracts are able to reduce blood cholesterol levels in rats fed with high cholesterol food and also in humans (Kalman et al., 2013). The observed serum cholesterol-lowering effects by $F$. deltoidea is shown to be mediated by pathways involved in lipid metabolism and transport, inflammation and immune response, antioxidant proteins, acute phase proteins, cholesterol homeostasis, fatty acid catabolism, and cholesterol binding (Chuo et al., 2020). Besides flavonoids, our previous qualitative study on the phytochemical screening of $F$. deltoidea aqueous extract has shown the presence of saponin and tannins (Zainudin et al., 2014), both of which, in combination, are reported to possess antioxidant as well as anticholesterol properties (Hagerman et al., 1998; Marelli et al., 2016). It is not known, however, whether the anticholesterol effects seen in the current study are due to the sequential effects of reduced oxidative stress or vice versa. Although in the current study the animals were first ovariectomized to mimic a menopausal state, therefore, the TC lowering effects observed is most probably due to the dual biological effects of $F$. deltoidea aqueous extract; antioxidant and anticholesterol.

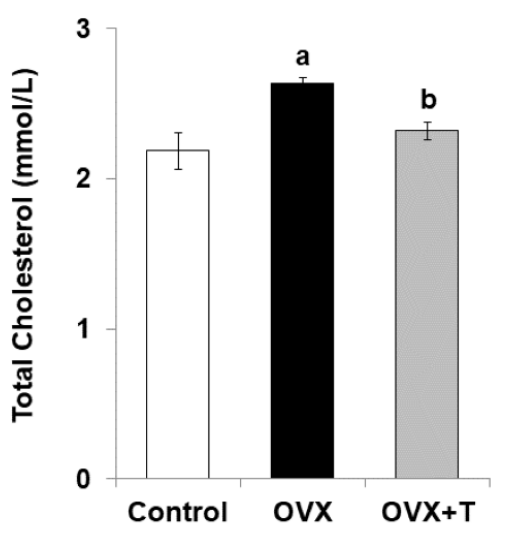

Figure 6.The serum cholesterol level in the ovariectomized rats. Data are presented as means \pm SEM. (a) Significant difference compared with control group ( $p<0.05$, and b) significant difference compared with OVX group ( $p<$ $0.05)$. 
Additionally, the toxicological evaluation was conducted on the leaves and it was found that it does not contain toxic elements while the number of heavy metals was reported to be within the acceptable limits (Armaghan et al., 2011). Thus, F. deltoidea holds a good prospect to be developed as an alternative supplement for postmenopausal women to prevent oxidative stress due to estrogen depletion.

\section{CONCLUSION}

Ficus deltoidea aqueous extract given as oral supplementation at $500 \mathrm{mg} / \mathrm{kg}$ was shown to prevent the oxidative stress induced by ovariectomy in the brain, liver, heart, and kidney of rats. Ficus deltoidea aqueous extract supplementation also decreased the cholesterol level in the serum of the ovariectomized rats. Taken together, $F$. deltoidea has the potential to be used as a supplement to improve the health status of postmenopausal women.

\section{ACKNOWLEDGMENTS}

This project was financially supported by FRGS/1/2011/ SKK/UKM/02/22 and Biomedical Science Program, Faculty of Health Sciences, Universiti Kebangsaan Malaysia (UKM).

\section{AUTHOR CONTRIBUTIONS}

All authors made substantial contributions to conception and design, acquisition of data, or analysis and interpretation of data; took part in drafting the article or revising it critically for important intellectual content; agreed to submit to the current journal; gave final approval of the version to be published; and agree to be accountable for all aspects of the work. All the authors are eligible to be an author as per the international committee of medical journal editors (ICMJE) requirements/guidelines.

\section{CONFLICTS OF INTEREST}

The authors report no financial or any other conflicts of interest in this work.

\section{ETHICAL APPROVAL}

This study was granted approval from the Universiti Kebangsaan Malaysia Animal Ethics Committee (UKMAEC): FSK/BIOMED/2012/FARAH/12- Dec/483.

\section{PUBLISHER'S NOTE}

This journal remains neutral with regard to jurisdictional claims in published institutional affiliation.

\section{REFERENCES}

Abdulla MA, Ahmed KA, Mohammad Abu-Luhoom F, Muhanid M. Role of Ficus deltoidea extract in the enhancement of wound healing in experimental rats. Biomed Res, 2010; 21(3):241-5.

Abdullah Z, Hussain K, Zhari I, Rasadah MA, Mazura P, Jamaludin F, Sahdan R. Evaluation of extracts of leaf of three Ficus deltoidea varieties for antioxidant activities and secondary meta-bolites. Pharmacognosy Res, 2009; 1:216-23.

Adam Z, Hamid M, Ismail A, Khamis S. Effect of Ficus deltoidea extract on blood glucose level in normal and mild diabetic rats. Malays $\mathrm{J}$ Health Sci, 2007; 5(2):9-16.

Aebi H. Catalase in vitro. Methods Enzymol, 1984; 105:121-6.

Aminudin N, Sin CY, Chee ES, Nee KI, Renxin L. Blood glucose lowering effect of $F$. deltoidea aqueous extract. Malays J Sci, 2007; 26(1):73-8.
Aris SRS, Mustafa S, Ahmat N, Jaafar FM, Ahmad R. Phenolic content and antioxidant activity of fruits of Ficus deltoidea var angustifolia $s p$. Malays J Anal Sci, 2009; 13(2):146-50.

Armaghan S, Elham F, Khadeer BMH, Jamshid MAS, Idress HA, Ismail Z, Zaini MA. Evaluation of toxicological and standardization parameter and phytochemical investigation of Ficus deltoidea. Am J Biochem Mol Biol, 2011; 1(3):237-43.

Aroka KS, Gupta N, Singh RA, Nagpal S, Arora D. Role of free radicals in menopausal distress. J Clin Diagn Res, 2009; 3:1900-2.

Azizan N, Mohd Said S, Zainal Abidin Z, Jantan I. Composition and antibacterial activity of the essential oils of orthosiphon stamineus benth and Ficus deltoidea jack against pathogenic oral bacteria. Molecules, 2017; 22:2135.

Barp J, Araújo ASR, Fernandes TRG, Rigatto KV, Llesuy S, Belló-Klein A, Singal P. Myocardial antioxidant and oxidative stress changes due to sex hormones. Braz J Med Biol Res, 2009; 35(9):1075-81.

Behl C, Skutella T, Lezuoalc'H F, Post A, Widmann M, Newton CJ, Holsboer F. Neuroprotection against oxidative stress by estrogens: structure-activity relationship. Mol Pharmacol, 1997; 51:535-41.

Beral V, Banks E, Reeves G. Evidence from randomised trials on the long-term effects of hormone replacement therapy. Lancet, 2002; 360(9337):942-4.

Beyer WF, Fridovich I. Assaying for superoxide dismutase activity: some large consequences of minor changes in conditions. Ana Biochem, 1987; 161(2):559-66.

Bittner V. Estrogens, lipids and cardiovascular disease: no easy answers. J Am Coll Cardiol, 2001; 37(2):431-3.

Borras C, Gambini J, Lopez-Grueso R, Pallardo FV, Vina J. Direct antioxidant and protective effect of estradiol on isolated mitochondria. Biochim Biophys Acta, 2010; 1802(1):205-11.

Bossé R, Di Paolo T. Dopamine and GABAA receptor imbalance after ovariectomy in rats: model of menopause. J Psychiatry Neurosci, 1995; 20(5):364-71.

Brunelli E, La Russa D, Pellegrino D. Impaired oxidative status is strongly associated with cardiovascular risk factors. Oxid Med Cell Longev, 2017; 2017:6480145.

Bunawan H, Mat Amin N, Bunawan SN, Baharum SN, Mohd Noor N. Ficus deltoidea: A review on its phytochemical and pharmacological importance. Evid Based Complementary Altern Med, 2014; $2014: 902734$.

Chuo PH, Uzar F, Abdul-Rahman PS, Abdullah N, Aminudin N. Alterations of cholesterol lowering-related proteins in the serum of hypercholesterolemic-induced rats treated with Ficus deltoidea. Sains Malays, 2020; 49(5):1055-66.

Doshi SB, Agarwal A. The role of oxidative stress in menopause. J Midlife Health, 2013; 4(3):140-6.

Dubey RK, Jackson EK. Estrogen-induced cardiorenal protection: potential cellular, biochemical, and molecular mechanisms. Ren Physiol, 2001; 280(3):365-88.

Ellman G. Tissue sulphydryl group. Arch Biochem Biophys, $1959 ; 32: 70-7$

Fang Y, Yang S, Wu G. Free radicals, antioxidants and nutrition. Nutrition, 2002; 18:872-9.

Fatihah HN, Mat N, Zaimah AR, Zuhailah MN, Norhaslinda H, Khairil M, Ghani AY, Ali AM. Morphological phylogenetic analysis of seven varieties of Ficus deltoidea Jack from the Malay Peninsula of Malaysia. PloS One, 2012; 7(12):e52441.

Firth JM, Yang HY, Francis AJ, Islam N, MacLeod KT. The effect of estrogen on intracellular $\mathrm{Ca}^{2+}$ and $\mathrm{Na}^{+}$regulation in heart failure JACC Basic Transl Sci, 2020; 5(9):901-12.

Glazier MG, Marjorie AB. A review of the evidence for the use of phytoestrogens as a replacement for traditional estrogen replacement therapy. Arch Intern Med, 2001; 161:1161-72.

Gluhovschi GH, Gluhovschi A, Anastasiu D, Petrica L, Gluhovschi C, Velciov S. Chronic kidney disease and the involvement of estrogen hormones in its pathogenesis and progression. Rom J Intern Med, 2012; 50(2):135-44. 
Guetta V, Cannon RO. Cardiovascualr effects of estrogen and lipid-lowering therapies in postmenopausal women. Circulation, 1996; 93(10):1928-37.

Ha BJ. Oxidative stress in ovariectomy menopause and role of chondroitin sulfate. Arch Pharm Res, 2004; 8:867-72.

Hagerman AE, Riedl KM, Jones A, Sowik KN, Ritchard NT, Hartzerfeld PW, Riechel TL. High molecular weight plant polyphenolics (tannins) as antioxidants. J Agric Food Chem, 1998; 46(5):1892-87.

Hakiman M, Maziah M. Non enzymatic and enzymatic antioxidant activities in aqueous extract of different Ficus deltoidea accessions. J Med Plants Res, 2009; 3(3):120-31.

Ibrahim FW, Derased NI., Zainudin URA, Mohammad N, Rajab NF. Mechanism identification of Ficus deltoidea aqueous extract in rat uterine contractions. Malaysian J Health Sci, 2018; 16(2018):75-81.

Kalman DS, Schwartz HI, Feldman S, Krieger DR. Efficacy and safety of Elaeis guineensis and Ficus deltoidea leaf extracts in adults with pre-diabetes. Nutr J, 2013; 12:36.

Kamran A, Hasseri H, Siong MC, Kalavathy R, Sadia S. In vitro antioxidant, antimicrobial and antiproliferative studies of four different extracts of Orthosiphon stamineus, Gynura procumbens and Ficus deltoidea. Saudi J Biol Sci, 2020; 27(1):417-32.

Kerstin S, Simone R, Sven W, Oliver A, Christian G, Kerstin L, Michael B, Georg N. Modulation of antioxidant enzyme expression and function by estrogen. Circ Res, 2003; 93:170-7.

Ledwozyw A, Michalak J, Stepien A, Kadziolka A. The relationship between plasma triglycerides, cholesterol, total lipids and lipid peroxidantion products during human atherosclerosis. Clin Chim Acta, 1986; 155(3):275-83.

Li SJ, Tao Y, Yang JQ. The role of cellular glutathione peroxidase redox regulation in the suppression of tumor cell growth by manganese superoxide dismutase. Cancer Res, 2000; 60:3927-39.

Lu SC. Regulation of glutathione synthesis. Mol Aspects Med, 2009.; 30(1-2):42-59.

Marelli M, Conforti F, Araniti F, Statti AA. Effects of saponins on lipid metabolism: a review of potential health benefits in the treatment of obesity. Molecules, 2016; 21:1404.

Misbah H, Abdul Aziz A, Aminudin N. Antidiabetic and antioxidant properties of Ficus deltoidea f ruit extracts and fractions. BMC Complement Altern Med, 2013; 13:118.

Murugananthan G, Sathya CP. Medicinal plants with potent antioxidant constituents. UPSR, 2012; 3(5):1268-73.

Nazrun AS, Khairunnur A, Norliza M, Ima Nirwana S. Effects of palm tocotrienols on oxidative stress and bone strength in ovarictomized rats. Med Health, 2008; 3(2):247-55.

Nihayah M, Yong KW, Abu Bakar NF. Determination of mineral content in the Ficus deltoidea leaves. Malays J Health Sci, 2012; 10(2):25-9.

Norbury R, Cutter WJ, Compton J, Robertson DM, Craiq M, Whitehead M, Murphy DG. The neuroprotective effects of estrogen on the aging brain. Exp Gerontol, 2003; 38:109-17.

Ogura S, Shimosawa T. Oxidative stress and organ damages. Curr Hypertens Rep, 2014; 16(8):452.

Oliveira MC, Campos-Shimada LB, Marçal-Natali MR, IshiiIwamoto EL, Salgueiro-Pagadigorria, CL. A long-term estrogen deficiency in ovariectomized mice is associated with disturbances in fatty acid oxidation and oxidative stress. Rev Bras Ginecol Obstet, 2018; 40(5):251-9.

Omar MH, Mullen W, Crozier A. Identification dimers and trimers, flavone C-glycosides, and antioxidant in Ficus deltoidea, a Malaysian herbal tea. J Agric Food Chem, 2011; 59:1363-9.

Paglia DE, Valentine WN. Studies on the quantitative and qualitative characterization of erythrocyte glutathione peroxidase. J Lab Clin Med, 1967; 70:158-69.

Peet M. Essential fatty acids: theoretical aspects and treatment implications for schizophrenia and depression. Adv Psychiatr Treat, 2002; 8:223-9.

Rosnani H, Choi HK, Roji MS, Park CS. 2012. Protective effects of a Ficus deltoidea (Mas cotek) extract against UVB-induced photoageing in skin cells. Biotechnol Bioprocess Eng, 2012; 18:185-93.
Ruzaina SA, Mustafa S, Ahmat N, Faridahanim MJ, Rohaya A. Phenolic content and antioxidant activity of fruits of Ficus deltoidea var Angustifolia sp. Malays J Anal Sci, 2009; 13(2):146-50.

Salvi M, Battaglia V, Brunati AM, Rocca NL, Tibaldi E, Pietrangeli P, Marcocci L, Mondovi B, Rossi CA, Toninello A. Catalase takes part in rat liver mitochondria oxidative stress defense. J Biol Chem, 2007; 282(33):24407-15.

Sánchez-Rodríguez MA, Zacarías-Flores M, Castrejón-Delgado L, Ruiz-Rodríguez AK, Mendoza-Núñez VM. Effects of hormone therapy on oxidative stress in postmenopausal women with metabolic syndrome. Int J Mol Sci, 2016; 17(9):1388.

Schirman-Hildesheim TD, Ben-Aroya N, Koch Y. Daily GnRH and $\mathrm{GnRH}$-receptor mRNA expression in the ovariectomized and intact rat. Mol Cell Endocrinol, 2006; 252(1-2):120-5.

Sen S, Chakrabort R, Sridhar C, Reddy YSR, De B. Free rdicals antioxidants, disease and phytomedicines: current status an future prospect. Int J Pharm Sci Rev Res, 2010; 3(1):91-100.

Shimizu I, Kohno N, Tamaki K, Shono M, Huang HW, He JH, Yao DF. Female hepatology: favorable role of estrogen in chronic liver disease with hepatitis B virus infection. World J Gastroenterol, 2007; 13(32):4295-305.

Sirisha N, Sreenivasulu M, Sangeeta K, Chetty CM. Antioxidant properties of Ficus species: a review. Int J Pharm Tech Res, 2010; 2(4):2174-82

Skafar DF, Xu R, Morales J, Ram J, Sowers JR. Clinical review 91: female sex hormones and cardiovascular disease in women. J Clin Endocrinol Metab, 1997; 82(12):3913-8.

Sridhar M, Ilangovan R, Balaganesh M, Veni S, Arunakaran J. Ovariectomy induces oxidative stress and impairs bone antioxidant system in adult rats. Clin Chim Acta, 2005; 360:81-6.

Stacie EG, Lee PS, Richard BB, Suzanne B, Ying Z, Geena E, Samad H, Dejan N, Elizabeth, CK, Colleen EP, Judy LLB, Guido FP, Norman RF. Safety and efficacy of black cohosh and red clover for the management of vasomotor symptoms: a randomized controlled trial Menopause, 2009; 16(6):1156-66.

Sulaiman MR, Hussain MK, Zakaria ZA, Somchit MN, Moin S, Mohamad AS, Israf DA. Evaluation of the antinociceptive activity of Ficus deltoidea aqueous extract. Fitoterapia, 2008; 79:557-61.

Taufik HM, Nurul Khalbi A, Zulkhairi A. Effect of Ficus deltoidea on cholesterol level and its antioxidant properties on lipid peroxidation in cholesterol-fed rats. Poster presented in Seminar on medicinal and aromatic plants. Kepong, Malaysia: FRIM, 2005.

Thomas P, Pang YF. Protective actions of progesterone in the cardiovascular system: potential role of membrane progesterone receptors (mPRs) in mediating rapid effects. Steroids, 2013; 78(6):583-8.

Timins JK. Current issues in hormone replacement therapy. N J Med, 2004; 101:21-7.

White RE, Gerrity R, Barman SA, Han G. Estrogen and oxidative stress: a novel mechanism that may increase the risk for cardiovascular disease in women. Steroids, 2010; 75(11):788-93.

WHO. Traditional medicine. Beijing, China: WHO Congress. 2008. Available via https://www.who.int/traditional-complementaryintegrative-medicine/about/beijing-congress/en/. (Accessed 01 October 2020).

Zainudin UA, Mohammad N, Ibrahim FW, Rajab NF. Phytochemical characteristic and uterotonic effect of aqueous extract of Ficus deltoidea leaves in rats uterus. Pak J Biol Sci, 2014; 17(9):1046-51.

How to cite this article:

Ibrahim FW, Abdullah AF, Chan YL, Jufri NF, Mohammad N, Rajab NF. Ficus deltoidea aqueous leaves extract abrogates enhanced-oxidative damage in ovariectomized rat models. J Appl Pharm Sci, 2021; 11(08):147-153. 